\title{
Changes in the Food Web Linked to Restoration Effort Intensity and Watershed Conditions
}

\author{
Lorraine Parsons $^{1 *}$, Lindsey Sanders ${ }^{2}$, Amelia Ryan1, Michael Reichmuth ${ }^{3}$ \\ ${ }^{1}$ Point Reyes National Seashore, National Park Service, Point Reyes Station, CA, USA \\ ${ }^{2}$ Forest Grove, OR, USA \\ ${ }^{3}$ Inventory and Monitoring Program, San Francisco Area Network, National Park Service, Point Reyes Station, \\ CA, USA \\ Email: ${ }^{*}$ Lorraine Parsons@nps.gov
}

Received 25 March 2015; accepted 13 May 2015; published 14 May 2015

Copyright (C) 2015 by authors and Scientific Research Publishing Inc.

This work is licensed under the Creative Commons Attribution International License (CC BY). http://creativecommons.org/licenses/by/4.0/

(c) (i) Open Access

\section{Abstract}

Many tidal wetland restoration projects have focused on changes in vegetation or avian communities to determine whether restoration efforts have been successful. However, a functioning restored ecosystem relies on complex interactions among organisms on every level of the food web. In 2008, more than 223 hectares (ha) of former dairy ranch were restored to tidal wetland in Tomales Bay, California. To evaluate changes, we monitored zooplankton, benthic invertebrate, and fish communities before and after restoration in the Project Area and several natural marshes. Zooplankton and benthic invertebrate communities differed from natural marshes prior to restoration, but began to converge with natural marshes after restoration in terms of species composition, richness, and diversity. Fish communities in the Project Area remained distinct from those of natural marshes after restoration, although abundance of non-native species decreased. In past studies, fish communities have changed more quickly than invertebrate ones. The divergent evolutionary path taken by this system may stem from differences in restoration approach. This project did not involve extensive excavation or fill with dredge spoil material, and this minimalistic approach may promote more rapid colonization by invertebrates, especially if source populations exist nearby. While convergence with natural marshes was an objective, rapid colonization may not be beneficial in this instance as natural marshes have turned out to be dominated by nonnative, opportunistic invertebrate species. Ultimately, success of restoration projects may be determined by factors extrinsic to the project itself such as climatic variability and prevalence of invasive species within watersheds.

"Corresponding author.

How to cite this paper: Parsons, L., Sanders, L., Ryan, A. and Reichmuth, M. (2015) Changes in the Food Web Linked to Restoration Effort Intensity and Watershed Conditions. Natural Resources, 6, 344-362. 


\section{Keywords}

\section{Restoration, Tidal Marsh, Invertebrates, Fish, Tomales Bay}

\section{Introduction}

The most widely studied indicators of change following wetland restoration are often parameters in which changes are readily visible - changes in vegetation communities or bird populations. However, changes in higher trophic orders of fish and birds are often dependent on changes in their prey base following restoration. In a wetland ecosystem, this prey base includes pelagic macro- and benthic invertebrates, as well as smaller fish. Successful restoration requires restoration of the entire food web, not just vegetation and higher level organisms.

Tidal wetland restoration efforts to date appear to have been relatively successful in rehabilitating fish populations. Fish abundance, species composition, and species diversity can change dramatically in the first few years after restoration with densities and species richness quickly resembling conditions observed in reference or natural marshes [1]-[6]. Some restored marshes have even supported higher fish densities and species richness than natural marshes [2] [3] and developed a species assemblage typical of reference marshes within 5 to 13 years [2] [4] [6]. There have been projects where fish use either did not compare favorably with reference marshes [7] or actually declined with restoration [8]. However, in these instances, either the types of habitat present in the natural marsh did not correspond well with those created in the restored site, or the restoration reduced potential fish habitat. Rather than being driven by restoration, age of restoration, or native marsh status, several projects found that differences between fish assemblages depended on the marsh channels' physical structure (e.g., width, depth, slope of bank, marsh elevation), as well as hydrologic and environmental conditions, including hydroperiod, temperature, dissolved oxygen, salinity, and flow discharge [1]-[3] [9].

Marsh status (restored vs. native) and age of restoration has played a more critical role in benthic invertebrate community development. Many studies found differences in benthic invertebrate communities between restored and reference marshes even 10 to 20 years after restoration [9]-[12]. Almost all prior studies have shown differences in community structure between constructed and natural marshes persisting within the first few years after restoration [10] [13] [14]. There are some exceptions: a restored marsh in southern California supported equivalent levels of macrofaunal densities, species richness, and diversity as that of the nearby reference marsh in 19 months, although species composition remained different [15]. A strong correlation appears to exist between time since restoration and many benthic parameters, with older marshes showing more structural similarities to natural marshes [3] [10] [11] [16]-[19]. Within 5 to 10 years, some marshes reached equivalence of invertebrate communities with natural marshes or even surpassed them in some parameters such as species diversity or density [2] [3] [11] [19].

Despite these successes, most studies have found that differences between natural marshes and their constructed counterparts persist long after restoration is implemented. At created marshes in Mississippi, community structure still differed between created and natural marshes even 27 years after construction, although species diversity and evenness was higher at created marshes [12]. In some New England marshes, the high marsh snail, Melampus bidentatus, took two decades to reach natural marsh densities [4]. This lack of convergence is attributed to a number of factors, including proximity to natural marshes that act as a source for invertebrate recolonization, elevation, belowground biomass of plants, macro-organic matter (MOM), soil organic C, total N, and substrate, with MOM sometimes considered one of the most important [3] [10]-[12] [14] [15] [18].

In 2008, the National Park Service (Park Service) finished a two-year project to restore more than 223 hectares (ha) of former tidal marsh known as Giacomini Wetlands at the head of Tomales Bay in Marin County, California [20] (Figure 1). As part of the project, the Park Service has been conducting pre- and post-restoration monitoring of hydrologic and ecological variables. For several years prior to restoration, we monitored zooplankton, benthic invertebrates, and fish to determine species assemblages and relative abundance while the Project Area was a dairy ranch. Here, we present comparative results from the first four years after restoration to evaluate how assemblages and abundance of invertebrates and fish have changed in response to the rapid conversion of pasture to salt, brackish, and freshwater marsh. We hypothesized that the structure of invertebrate and fish communities would dramatically change following restoration, but that it would not have fully converged 


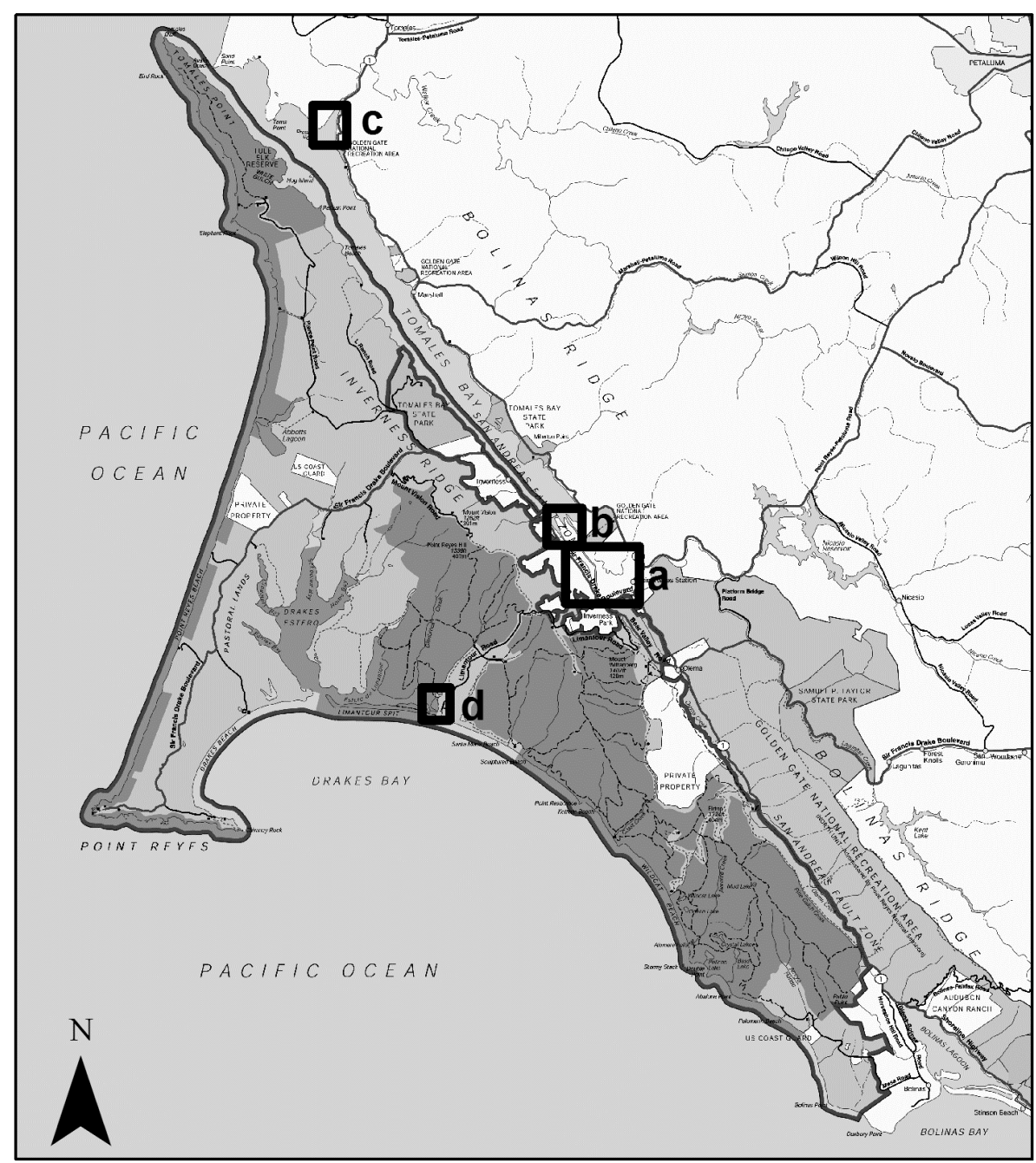

Figure 1. Location of (a) Giacomini Wetland Restoration Project Area (PA); (b) Lagunitas Creek Undiked Salt Marsh (Ref); (c) Walker Creek Marsh (Ref), and (d) Limantour Marsh (Ref) within the Point Reyes National Seashore.

yet with that of natural marshes. Understanding the structure of the prey base available in the marsh before and after restoration will help us to better understand changes in use of the restored habitat by birds and larger fish species and the ecological contribution of this restoration project to a complex watershed ecosystem.

\section{Materials and Methods}

\subsection{Study Areas}

The Study Areas are located in Tomales Bay and Estero de Limantour, both of which are located on the central California Coast in Marin County just north of San Francisco, USA. Tomales Bay proper is a $28 \mathrm{~km}^{2}$ shallow, highly unidirectional, Mediterranean-type, coastal estuary [21]. Estero de Limantour is very similar to Tomales Bay, but much smaller in size $\left(0.91 \mathrm{~km}^{2}\right)$ [22]. Despite its proximity to the highly urbanized San Francisco Bay area, the Tomales Bay watershed remains largely agricultural, supporting a number of beef and dairy cattle ranches [21], The Estero de Limantour watershed was once more extensively farmed, although these activities have been scaled back now that watershed lands are part of the national park system [23].

The Study Areas included the Project Area (PA; labeled "a" on Figure 1), Reference Areas (REF), which are natural tidal marshes in Tomales Bay and adjacent watersheds (Walker Creek Marsh (labeled "c" on Figure 1, Limantour Marsh (labeled "d” on Figure 1), and the Undiked Marsh (labeled "b” on Figure 1). In addition, for 
some variables, additional sampling was conducted in sites upstream of the Project Area (Upstream Areas; US) to determine whether conditions in the leveed dairy ranch were actually more similar to upstream freshwater or mildly brackish creek areas than natural tidal marshes.

The Project Area occurs in the very southern portion or the headwaters of Tomales Bay [20]. During establishment of a dairy ranch in 1946, this area was leveed off from adjoining natural marshes to the north and from one of the watershed's largest sources of freshwater inflow, Lagunitas Creek, which bisects the Project Area into two areas that are approximately 142 ha (East) and 81 ha (West) in size [20] [21]. Despite being leveed, the former tidal wetlands had not subsided in elevation relative to adjacent natural marshes more than 0.3 to 0.6 meters ( $\mathrm{m}$; [24]).

Three reference wetlands represented the natural variability present in nearby tidal marshes that are somewhat similar to the Project Area in terms of site and watershed size, marsh age, land use, and marsh formation history, although hydrologic conditions may be slightly different due to variation in freshwater and tidal inflow. During the late $19^{\text {th }}$ and early $20^{\text {th }}$ centuries, logging and agricultural development caused a substantial increase in sedimentation within Tomales Bay, and marshes were formed or enlarged at the mouths of Lagunitas and Walker Creeks (the Undiked Marsh and Walker Creek Marsh, respectively; [25]). The Undiked Marsh and Giacomini Wetlands once formed an integrated wetland complex, until levee construction divided the two areas. Limantour Marsh, the third reference site, is adjacent to the Pacific Ocean in a different watershed and has a much smaller watershed size and a slightly different formation and land use history: it was formed in the 1960s after an upstream dam was installed [20].

\subsection{Restoration Project Background}

The Park Service bought the Giacomini Ranch dairy for wetland restoration in 2000 [20]. Extensive changes in watershed condition including huge influxes of sediment following logging in the late 1800s precluded re-creating historic conditions, so, instead, the Park Service focused on restoring natural hydrologic and ecological processes and functions [20]. After seven years of planning, restoration of approximately 223 ha was implemented in 2007 and 2008 [20]. Because of constraints related to subsidence (e.g., reductions in vertical elevations after long-term leveeing) or to adjacent infrastructure, many other tidal marsh restoration projects in California (e.g., South Bay Salt Ponds, Hamilton Wetlands, Bolsa Chica) involve elaborately phased designs, construction of interim levees, extensive excavation or fill, or placement of dredgespoil materials. In comparison, restoration efforts for this project were relatively minimal, mainly involving removal of agricultural infrastructure, including 4 kilometers $(\mathrm{km})$ of levee, tidegates, and culverts [20]. A linear system of drainage ditches was filled with levee material, and $3.7 \mathrm{~km}$ of new tidal channels were created [20]. Other than channel creation, the only other major excavation was shallow grading of 6.5 ha of uplands into intertidal zones and floodplains [20].

\subsection{Monitoring Design}

The framework for Park Service's long-term monitoring program was a modified, asymmetrical BACI (BeforeAfter-Control-Impact) sampling approach [26]. This sampling design is well-suited to restoration monitoring in that it evaluates conditions in the Project Area (PA; "impact area") before and after restoration and uses several natural marshes or Reference Areas (REF; "control") to differentiate between effects of restoration and other factors and to determine similarity of the restored marsh to natural marshes. Monitoring took place for seven to eight years depending on the variable, with four years of monitoring preceding restoration ("Before" 2005-2008) and generally four years following restoration ("After” 2009 - 2012), with the exception of benthic invertebrate sampling, which was only conducted for three years post-restoration.

\subsection{Sampling Methodology: Zooplankton}

Invertebrate communities were sampled at approximately 28 sites (median) twice annually: in spring (April/May) and fall (October/November) to coincide with spring peaks in productivity and fall shorebird migration. The number of sampling sites varied due to changes in aquatic habitats present due to restoration, seasonal drying up of some features such as creeks, and other factors, with the number of sites ranging from 10 to 37 over this period. Approximately 12 of these sites were in the Project Area, while the remainder was either in Control or Reference Areas (10) or Upstream Areas (US; 6). Sampling was conducted in a variety of aquatic habitats, including sloughs and creeks, drainage ditches, ponds, and shallowly ponded areas (e.g., flooded pannes). Zoop- 
lankton sampling characterized the aquatic invertebrate community within the water column. Vertical tows were conducted using a 63 um mesh plankton Nitex net (Turtox; Wildlife Supply Company; Saginaw, Michigan) with a weighted bottom. Two tows were conducted at each sampling site. Both tows were poured into a 250-ml jar and fixed with 10 percent formalin in the field. The samples were sent to a biologist (Anne Slaughter, San Francisco State University, Romberg-Tiburon Center for Environmental Studies, Tiburon, CA) with expertise in zooplankton taxonomy for identification to either genus or species level. Density data were obtained by calculating the volume of water towed: (Length of tow) ( $\pi$ ) (Radius of net opening) ${ }^{2}$.

\subsection{Sampling Methodology: Benthic Invertebrates}

Benthic invertebrate samples were collected at low tide once annually in November or December to correspond with fall and early winter shorebird migration. Sampling was conducted at approximately 27 sites (median) -- 14 in the Project Area and 13 in Control or Reference Areas. The number of sampling sites did vary slightly each year due to changes in aquatic habitat features following restoration and other factors, ranging from 23 to 30 . Starting in 2007, three samples of the top $5 \mathrm{~cm}$ of sediment were collected at each sampling site using a benthic corer (10-cm diameter). Initial sampling in 2005 and 2006 involved more subsamples (up to six) and deeper core depths (up to $15 \mathrm{~cm}$ ), but sampling depth was reduced in the third year, because, in most cases, the majority of infauna is located within the upper 2- to $5 \mathrm{~cm}$ of the sediment surface [16] [27]. These subsampling cores were then pooled for sorting and identification. For density analysis, abundances were adjusted to reflect a standardized reporting unit $\left(\right.$ density $/ \mathrm{cm}^{3}$ ), which represented a fraction of the total sediment volume sampled in all years. For analysis of species richness and associated indices, the initial sampling years were removed the data, as information available on samples did not allow for possible correction of data using other methods (e.g., rarefaction curves). Low abundance taxonomic groups with either combined with others or deleted, which resulted in 73 groups for analysis.

Samples were rinsed with water within 3 - 4 hours of collection and left overnight in a preservative of 37\% formaldehyde solution and water. After 24 - 48 hours, the samples were rinsed a second time and placed in a $70+\%$ Ethanol solution for shipping to a biologist with expertise in benthic invertebrate taxonomy (Susan McCormick, Auburn, CA), who sorted and identified to the lowest taxonomic level possible under 8X magnification (i.e., order, genus, or species).

\subsection{Sampling Methodology: Fish}

Fish sampling occurred twice annually: in early summer (June) and in fall (October). Fish sampling dates were intended to coincide with other ecological parameters such as migration of salmonids. Sampling was conducted at approximately 33 sites (median)--16 in the Project Area; 14 in Reference Areas; and 3 in Upstream Areas. The number of sampling sites did vary slightly each year due to changes in aquatic habitat features following restoration and other factors, ranging from 23 to 30. Fish sampling within tidal and diked wetlands presented special challenges due to the diversity of aquatic habitats (e.g., small and large creeks, ponds) and types of fish species present (i.e., demersal or bottom-dwelling species, fast-moving species, species present only at certain times of year).

Block nets and beach seines were used in smaller creeks within Study Areas. In wider creeks, a beach seine without blocking net was employed, although this method did not allow for reliable estimation of fish densities. Blocking nets and seines employed a multiple-pass depletion method in which seining was performed until all fish were caught or until numbers caught on three successive seines continued to decrease appreciably after each "pass." Dimensions of the blocking and seine nets varied depending on the size of the channel. Net length ranged from $15 \mathrm{~m}$ to $45 \mathrm{~m}$, with mesh size ranging from $0.31 \mathrm{~cm}$ to $0.625 \mathrm{~cm}$. Fish were placed into aerated buckets for identification and counting and were released upon completion of measurements at the capture site.

\subsection{Sampling Methodology: Water Quality}

During all zooplankton, benthic invertebrate, and fish sampling events, information was collected on water chemistry including water temperature $\left({ }^{\circ} \mathrm{C}\right.$ ), salinity (parts per thousand; ppt), dissolved oxygen (mg/L), $\mathrm{pH}$, and water depth (cm) using several models of hand-held YSI multi-parameter instruments (YSI Inc., Yellow Springs, Ohio). Water depth during each sampling event was measured using a rod with markings in centimeters (cm). 


\subsection{Data Analysis}

Total densities and species richness, diversity, and composition for zooplankton and benthic invertebrate data were compared between Pre- and Post- Restoration periods in the Study Areas and between the Project Area and Reference Areas. Pre-Restoration analysis of zooplankton data also incorporated areas upstream of the Project Area (US): Because the project objective is to restore the historic tidal marsh to conditions similar to those of other salt marshes, the US comparison was dropped from post-restoration analyses.

For univariate variables, data were analyzed using General Linear Model ANOVA (GLM; MiniTab v15.1, MiniTab Inc., State College, PA) if they met assumptions of parametric statistical methods. Environmental variables were included when appropriate as covariates. We also assessed whether results from successive sampling events were temporally autocorrelated using the ACF (Autocorrelation Function) and PACF (Partial Autocorrelation Functions): data did not show strong auto-correlation (all ACF and PACF > 0.05). If data did not meet parametric assumptions, they were either transformed, or non-parametric statistics were used. Non-parametric statistical tests included Kruskal-Wallis and Mood Median Test (MiniTab v15.1, MiniTab Inc, State College, PA). Arithmetic means are presented with standard error of the mean ( \pm S.E.).

We analyzed community data using several multivariate statistical analysis methods (Multi-response Permutation Procedure (MRPP), Indicator Species Analysis, and Non-Metric Multidimensional Scaling (NMS); PcOrd v5.3.1, MjM Software, Gleneden Beach, OR). NMS was used to evaluate differences in community structure in sampling sites between Pre- and Post- Restoration periods and between the Project Area, Reference Areas, and, if applicable, Upstream Areas. NMS was run using Relative Sørenson Distance, 50 runs with real data, 250 runs with random data, random starting co-ordinates, stability criterion 0.00005 , and a maximum number of dimensions/axes $=3$. The ordination was re-run manually five times to ensure that final stress scores between each run remained relatively stable and did not exceed 20. NMS results were examined further by running a GLM ANOVA model on the primary axis variables to look for significant differences between sites in terms of treatment groups or Study Areas.

Evaluation of group differences for multivariate data were carried out using MRPP and Indicator Species Analysis, which detects species that "indicate" a priori groups by evaluating relative frequency and abundance among groups using a Monte Carlo randomization procedure to evaluate significance (PcORD v.5.3.1). Statistical analyses also incorporated diversity measures, including species richness (total number of species) and the Shannon-Weiner Diversity Index (H'), which evaluates species richness and the proportion of each species. Diversity was defined as $\mathrm{H}^{\prime}=-\sum_{i=1}^{s} p_{i} \ln p_{i}$ where $S$ is the total number of species in the community and $p_{i}$ is the proportion of $S$ made up of species $i$.

Sampling techniques for fish did not allow for calculation and comparison of total densities or other quantitative abundance measures. However, the same type of sampling approach (e.g., block net; beach seine, etc.) was generally used at each site during every sampling period, so numbers can be considered a comparison of relative abundances at sites during different restoration periods. Similar multivariate techniques were used to analyze these relative abundances.

\section{Results}

\subsection{Zooplankton}

\subsubsection{Baseline Conditions}

Prior to restoration, zooplankton communities in the Project Area, Reference Areas, and Upstream Areas differed in abundance and species richness, diversity, and composition. Densities differed between Study Areas and sampling events (GLM; $\mathrm{df}=2, \mathrm{~F}=1.9, \mathrm{P}=0.04$; log-transformed), with average densities higher in the Project Area $\left(103,279 \pm 26,141\right.$ (S.E.) indiv $\left./ \mathrm{m}^{3}\right)$ than in either natural marshes $\left(64,233 \pm 22,154 \mathrm{indiv} / \mathrm{m}^{3}\right)$ or Upstream Areas (25,811 $\pm 12,733$ indiv $/ \mathrm{m}^{3}$; Figure 2). Median densities were 21,046 indiv $/ \mathrm{m}^{3}$ in the Project Area, 10,823 indiv $/ \mathrm{m}^{3}$ in the Reference Areas, and 3,657 indiv $/ \mathrm{m}^{3}$ in Upstream Areas (Mood Median; $\mathrm{df}=2$, Chi-Square $=$ 10.2, $\mathrm{P}=0.006$; Figure 2). In terms of environmental factors used as covariates, only $\mathrm{pH}$ appeared to be associated with differences in densities $(\mathrm{F}=4.1, \mathrm{P}=0.05)$.

As with abundance, species richness and diversity indices also showed some interaction between Study Area and individual sampling events. Mean species richness averaged $9.2 \pm 0.4$ in Reference Areas and 8.4 in both the Project Area $( \pm 0.4)$ and Upstream Areas $( \pm 0.6$; GLM, df = 2, F = 2.65, P = 0.004). Shannon-Weiner Diver- 


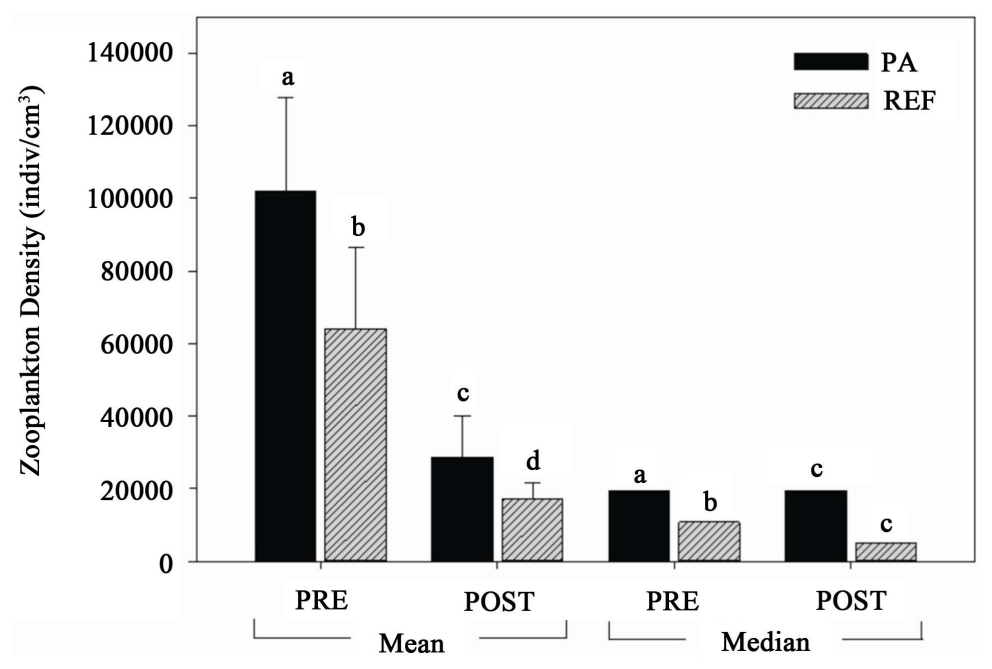

Figure 2. Mean and median densities of zooplankton in the Project Area during Pre- and Post-Restoration. Bars on mean densities indicate standard errors. Statistically significant differences as indicated by GLM or Mood Median Test are shown with letters above the density bars.

sity Index (H') averaged $1.19 \pm 0.06$ in the Project Area, $1.32 \pm 0.06$ in Reference Areas, and $1.37 \pm 0.09$ in Upstream Areas $(\mathrm{GLM}, \mathrm{df}=2, \mathrm{~F}=1.9, \mathrm{P}=0.04)$.

Based on MRPP results, Reference Areas had a very different mix of zooplankton species than either the Project Area ( $\mathrm{P}=0.0005)$ or Upstream Areas $(\mathrm{P}<0.0001)$, with the latter two being somewhat similar in species composition $(\mathrm{P}=0.12)$ despite the seemingly large habitat type differences expected between managed pasture and freshwater creek areas (MRPP, $\mathrm{df}=2, \mathrm{~T}=-6.22, \mathrm{P}<0.0001$ ). Multivariate ordination using NMS showed similar results with the largest separation in species assemblages being between the Project Area and Reference Areas, with Upstream Area sites being intermixed with Project Area ones (NMS, Final Stress $=15.66$, 3D solution, instab. $=0.00005,400$ iter; Figure 3(a)). Axes 1 and 2 cumulatively accounted for $55 \%$ of the $78 \%$ of the total variance accounted for by the data. Axis 2 of NMS differentiated species communities within the Project Area and Reference Area sampling sites, showing a strong salinity gradient between the two Study Areas (Kruskal-Wallis, $\mathrm{df}=2, \mathrm{H}=13.01, \mathrm{P}=0.001$ ), while Axis 1 showed more of a separation within Study Areas (GLM, df = 2, F = 4.62, P = 0.015; log-transformed).

Indicator Species Analysis suggested that, prior to restoration, Reference Areas were best separated from other Study Areas by Acartia spp. (Calanoida), Pseudobradya spp. (Harpacticoida), Monocorophium sp. (Corophiidae), Nippoleucon spp. (Cumacea), Cumaceans, and Nematodes (Monte Carlo, all P $<0.01$ ) and, to a lesser extent, Cyclopoids, Harpacticoids, and Oligochaetes (Monte Carlo, all $\mathrm{P}<0.10$ ). Diptera, Insecta, and Rotifera were the only taxa that appeared to distinguish the unrestored Project Area (Monte Carlo, all $\mathrm{P}<0.04$ ).

\subsubsection{Changes in Project Area with Restoration}

Densities of zooplankton actually decreased following restoration of the Project Area (GLM, $\mathrm{df}=1, \mathrm{~F}=16.5, \mathrm{P}$ $<0.0001$, log-transformed). As noted earlier, pre-restoration, densities of zooplankton averaged 103,279 \pm $26,141 \mathrm{indiv} / \mathrm{m}^{3}$, while, following restoration, densities averaged only 28,748 $\pm 11,357 \mathrm{indiv} / \mathrm{m}^{3}$ (Figure 2). These results appeared to be associated with changes in temperature of Project Area waters $(\mathrm{F}=10.9, \mathrm{P}=$ $0.001)$.

While zooplankton densities declined, species richness and diversity in the Project Area increased after restoration. The unrestored wetland had significantly lower numbers of zooplankton species ( $8.4 \pm 0.4$ than the restored one $(11.5 \pm 0.4$; GLM, $\mathrm{df}=1, \mathrm{~F}=13.19, \mathrm{P}<0.0001)$. The Pre-Restoration phase also supported communities with lower mean species diversity indices $\left(H^{\prime}=1.19 \pm 0.06\right)$ than the Post-Restoration one $\left(H^{\prime}=1.42 \pm\right.$ 0.06 ; GLM, df = 1, F = 7.66, P = 0.006).

Species composition shifted substantially in the Project Area after restoration (MRPP, $\mathrm{df}=1, \mathrm{~T}=-6,87, \mathrm{P}<$ 0.0001). Multivariate ordination showed separation between communities between the Pre- and Post-Restoration periods (NMS, Final Stress $=13.87$, 3D solution, instab $=0.00005$, 88 iter). Axes 2 and 3 showed the 

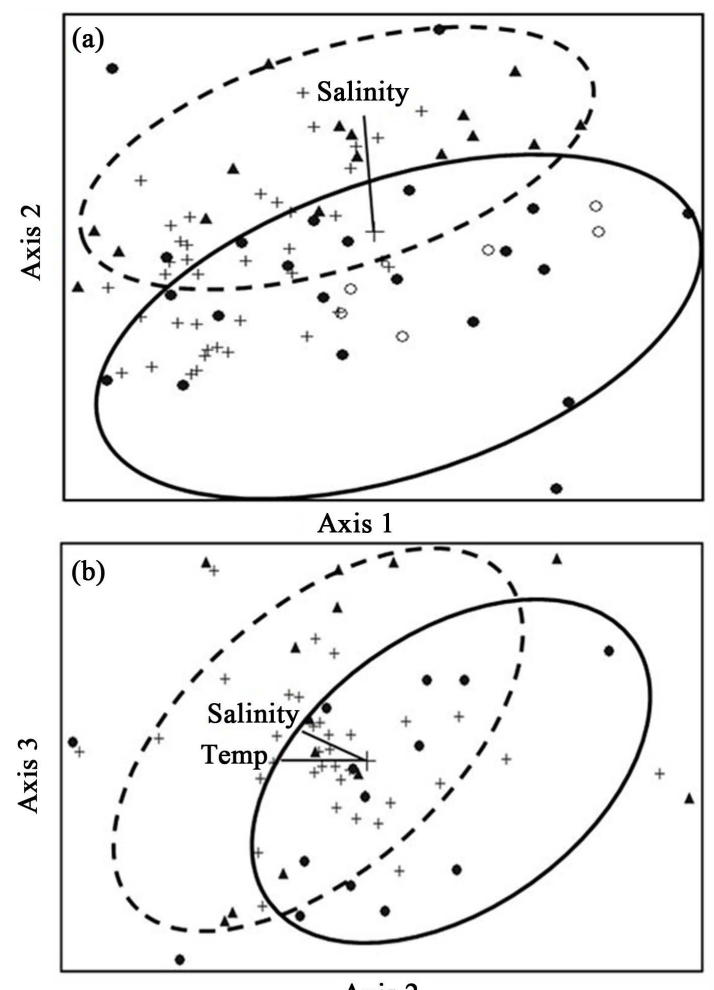

Axis 2

\begin{tabular}{|lrrr|}
\hline Study Areas: & - PA & -- Ref & + Species \\
Individual Sites: & O PA & $\Delta$ Ref & O US \\
\hline
\end{tabular}

Figure 3. Three-dimensional (3D) statistical ordination of zooplankton species assemblages and environmental variables using Non-Metric Multi-Dimensional Scaling between Study Areas for (a) Pre-Restoration with joint plot (Final stress $=15.66$ ) and (b) Post-Restoration with joint plot (Final Stress $=12.33$ ). Salinity accounted for some of the separation between Study Areas during Pre-Restoration period, while salinity and temperature differentiated Study Areas Post-Restoration. Pre-Restoration period includes comparison with upstream freshwater sites (US), as wetlands in leveed ranch were largely freshwater, but this comparison was omitted from post-restoration analyses.

highest incremental $\mathrm{R}^{2}$ values, cumulatively accounting for $61 \%$ of the $78 \%$ of total variance accounted for by the data. Most of the group separation came from Axis 3 (Kruskal-Wallis, df $=1, \mathrm{H}=12.28, \mathrm{P}<0.0001$ ), which separated Pre- and Post-Restoration communities. Salinity appeared to most strongly differentiate between restoration phases on Axis 3.

A large number of species demonstrated statistically significant indicator values following restoration of the Project Area, suggesting a considerable shift in species composition or dominance over the restoration period. Based on Indicator Species analysis, Pre-Restoration communities in the Project Area were distinguished from Post-Restoration ones by taxa including Diaptomus spp. (Calanoida), Pseudobradya sp. (Harpacticoida), Oncea spp. (Poecilostomatoida), Hydroida sp. (Cnidaria), Amphipoda, Corophiidae, Gammaridae, Rotifera, Nematoda, Oligochaeta, and Gastropoda (Monte Carlo, all P < 0.03). Only two species distinguished the restored wetland: Copepoda and Daphnia spp. (Cladocera; Monte Carlo, all P < 0.02).

\subsubsection{Convergence with Natural Marshes}

Following restoration, mean zooplankton densities continued to differ between Study Areas and sampling events (GLM, df = 7, F = 3.05, P = 0.005; log-transformed for analysis; Figure 2). Mean densities were still higher in the restored Project Area $\left(28,748 \pm 11,357 \mathrm{indiv} / \mathrm{m}^{3}\right)$ than in Reference Areas $\left(17,273 \pm 4,171 \mathrm{indiv} / \mathrm{m}^{3}\right) \mathrm{despite}$ declines in zooplankton abundance in the Project Area after restoration. However, densities also dropped significantly in natural marshes after 2008 (GLM, df = 1, F = 9.94, P = 0.002; Figure 2). Of environmental variables, water temperature had the strongest relationship with Post-Restoration densities $(\mathrm{F}=17.4, \mathrm{P}<0.0001)$. Median 
densities in the Project Area $\left(4,990 \mathrm{indiv} / \mathrm{m}^{3}\right)$ and Reference Areas (3,567 indiv/ $\mathrm{m}^{3}$ ) approximated each other more closely (Mood Median; $\mathrm{df}=1$, Chi-Square = 2.29, $\mathrm{P}=0.13$; Figure 2).

The restored Project Area and natural marshes also supported similar numbers and diversities of species. Following restoration, species richness averaged $11.5 \pm 0.4$ in the Project Area, compared to $10.5 \pm 0.4$ in Reference Areas (GLM, df $=1, \mathrm{~F}=1.72, \mathrm{P}=0.196)$. After 2008, species richness increased in Reference Areas (GLM, df $=1, F=4.76 . P=0.03$ ), as well as the Project Area. For the Shannon-Weiner diversity index, the Project Area averaged $1.42 \pm 0.06$, while Reference Areas averaged $1.36 \pm 0.07(\mathrm{GLM}, \mathrm{df}=1, \mathrm{~F}=0.07, \mathrm{P}=$ 0.80). There was no change in diversity indices in Reference Areas from Pre-Restoration $\left(\mathrm{H}^{\prime}=1.32 \pm 0.06\right)$ to Post-Restoration $\left(\mathrm{H}^{\prime}=1.36 \pm 0.07\right.$; $\left.\mathrm{GLM}, \mathrm{df}=1, \mathrm{~F}=0.87, \mathrm{P}=0.35\right)$.

Species assemblages also became more similar between the restored Project Area and natural marshes (MRPP, $\mathrm{df}=1, \mathrm{~T}=-0.50, \mathrm{P}=0.25$ ). Multivariate ordination showed overlap between some of the Project Area and Reference Area sites (NMS, Final Stress $=12.33$, 3D solution, in stab $=0.00004$, 96 iter; Figure 3(b)). Axes 2 and 3 accounted for $55 \%$ of the $78 \%$ of total cumulative variance $\left(\mathrm{R}^{2}\right)$ accounted by the data. Study Areas were differentiated primarily by salinity and temperature on Axis 2 (Kruskal-Wallis, $\mathrm{df}=1, \mathrm{H}=3.96, \mathrm{P}=0.05$; Figure 3(b)).

Despite these multivariate analyses results, Indicator Species analysis still found compositional differences. Taxa including Diaptomus spp. (Calanoida), Bosmina spp. (Cladocera), Brachionus spp. (Rotifera), Gammaridae (Amphipoda), and Rotifera were indicative of the Project Area (Monte Carlo, all $\mathrm{P}<0.03$ ), while Reference Areas showed only a few statistically weaker associations with taxa such as Acartia spp. (Calanoida) and Cyclopoda (Monte Carlo, all $\mathrm{P}<0.12$ ).

\subsection{Benthic Invertebrates}

\subsubsection{Baseline Conditions}

Prior to the restoration, the Project Area had significantly lower average benthic invertebrate densities than Reference Areas (GLM, df $=1, \mathrm{~F}=27.00, \mathrm{P}<0.001$, square-root transformed; Figure 4). The Project Area averaged $0.15 \pm 0.04$ inverts $/ \mathrm{cm}^{3}$, compared $0.85 \pm 0.15$ inverts $/ \mathrm{cm}^{3}$ within Reference Areas. The Study Areas also showed significant differences in species richness and diversity $\left(\mathrm{H}^{\prime}\right)$. The Project Area had significantly lower levels of richness $(16.4 \pm 2.46)$ and diversity $\left(\mathrm{H}^{\prime}=1.46 \pm 0.10\right)$ than Reference Areas (richness $=32.14 \pm 2.46$, GLM, $\mathrm{df}=1, \mathrm{~F}=20.47, \mathrm{P}<0.001$; and $\mathrm{H}^{\prime}=1.88 \pm 0.08$, GLM, $\mathrm{df}=1, \mathrm{~F}=10.49, \mathrm{P}=0.003$ ).

In addition to abundance and diversity differences between Study Areas prior to restoration, MRPP analysis pointed to species assemblages also being significantly different (MRPP, $\mathrm{df}=1, \mathrm{~T}=-6.28, \mathrm{P}<0.001$ ). NMS

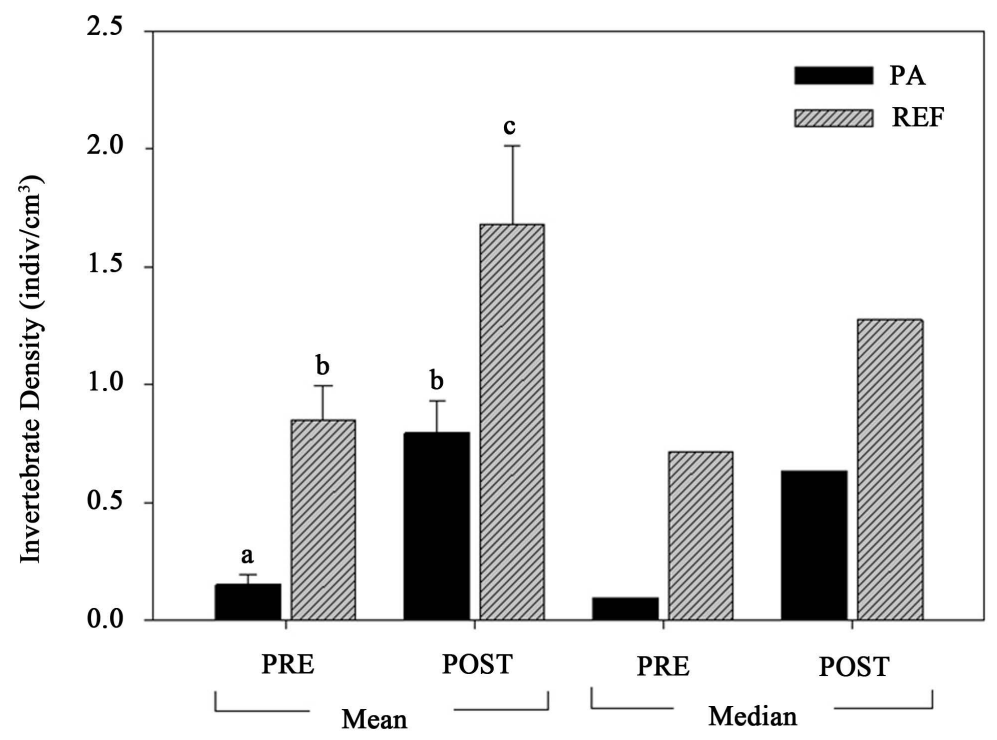

Figure 4. Mean and median benthic invertebrate density in the Project Area and Reference Area Pre- and Post-Restoration. Bars on mean densities indicate standard errors. Statistically significant differences as indicated by GLM are shown with letters above density bars. 
ordination showed natural marshes as tightly grouped in one corner of the ordination plot and distinctly separate from the relatively loosely clumped Project Area sites (NMS, Final Stress $=10.49$, 2D solution, instab $<0.064$, 400 iter; Figure 5(a)). Axis 2 significantly differentiated Study Areas (GLM, df = 1, F = 95.98, $\mathrm{P}<0.001$ ). Temperature, salinity, and $\mathrm{pH}$ had the strongest effect on spatial distribution of sampling sites (Figure 5(a)). Only temperature exhibited a significant effect on species composition within sampling sites (GLM, Temperature: $\mathrm{df}=1, \mathrm{~F}=3.15, \mathrm{P}=0.088, \mathrm{R}^{2}=20 \%$; Salinity: $\mathrm{df}=1, \mathrm{~F}=0.23, \mathrm{P}=0.638 ; \mathrm{R}^{2}=35 \%$; $\mathrm{pH}: \mathrm{df}=1, \mathrm{~F}=2.75$, $\mathrm{P}=0.109, \mathrm{R}^{2}=57 \%$ ).

Pre-Restoration, the Project Area had lower densities and a different mix of nematode, oligochaete, polychaete, and amphipod species than Reference Areas (MRPP, $\mathrm{df}=1, \mathrm{~T}=-2.65, \mathrm{P}=0.02$; Figure 6). There were some similarities: oligochaetes were by far the most prevalent higher order taxonomic group in both the Project Area $\left(0.06 \pm 0.02\right.$ inverts $\left./ \mathrm{cm}^{3}\right)$ and Reference Areas $\left(0.28 \pm 0.06\right.$ inverts $\left./ \mathrm{cm}^{3}\right)$, while amphipods were the least prevalent group in Reference Areas $\left(0.10 \pm 0.02\right.$ inverts $\left./ \mathrm{cm}^{3}\right)$ and one of the least prevalent in the Project Area $\left(0.01 \pm 0.01\right.$ inverts $/ \mathrm{cm}^{3}$; Figure 6$)$. In terms of lower order taxonomic groups, the benthic invertebrate species assemblage of the Project Area prior to restoration was composed largely of Potamopyrgus antipodarum (Gastropoda; 17\% of all species), Cyprideis (Ostracoda; 8\% of all species), and Nematostella vectensis (Actinaria; 6\% of all species). Indicator Species Analysis revealed Chironomidae (Diptera) to be the only taxa weakly indicative of the Project Area Pre-Restoration (Monte Carlo, $\mathrm{P}=0.057$ ). The most common taxonomic groups at the Reference Areas prior to restoration were Streblospio benedicti (Polychaeta; 8\% of all species) and Capitella

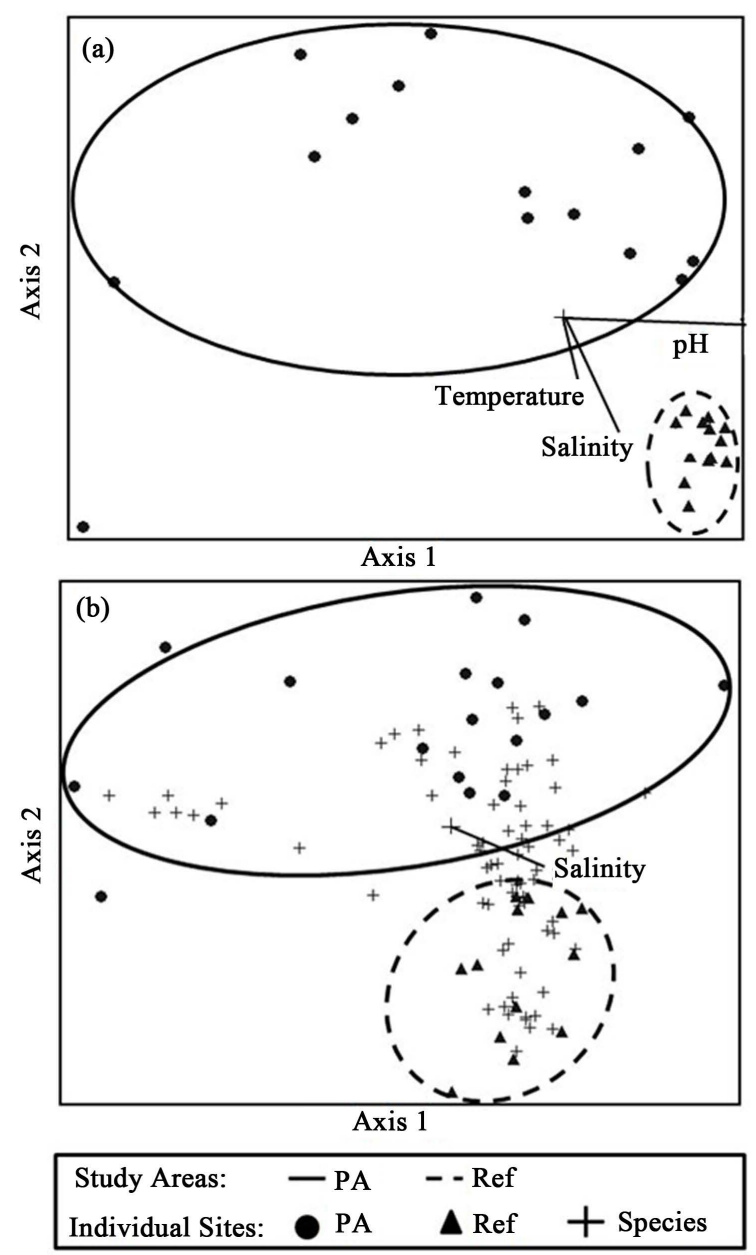

Figure 5. Two-dimensional (2D) statistical ordination of benthic invertebrate species assemblages and environmental variables using Non-metric Multi-dimensional Scaling between Study Areas for (a) PreRestoration with joint plot (Final stress $=10.49$ ) and $(b)$ Post-Restoration with joint plot (Final stress = 14.79). Salinity accounted for a moderate amount of variation between Study Areas Post-Restoration. 


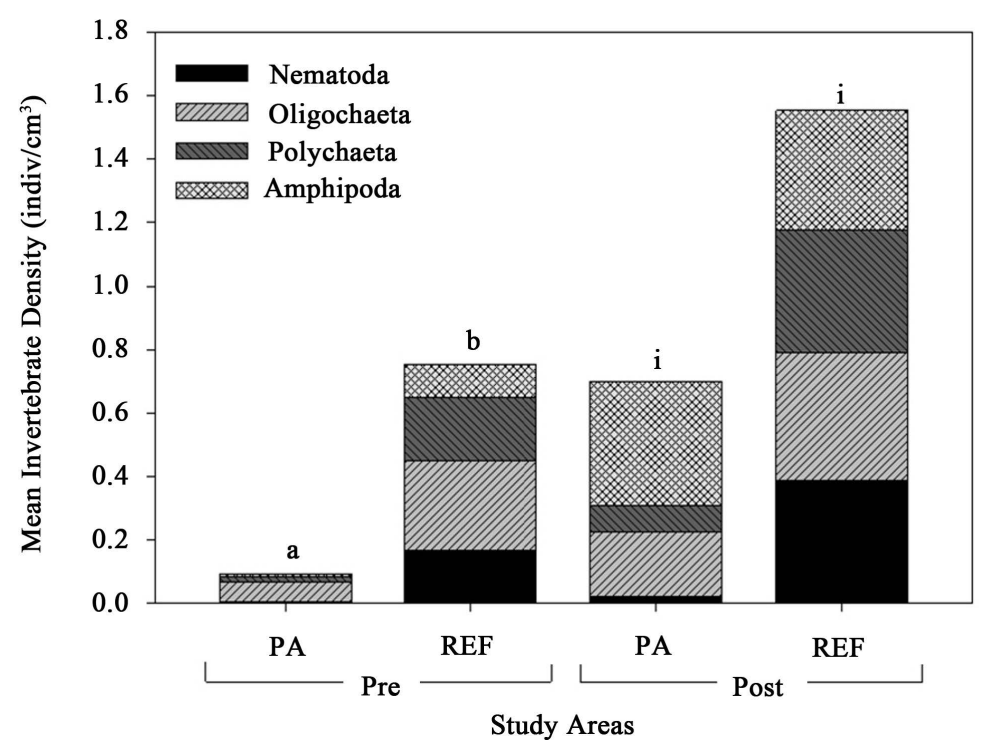

Figure 6. Mean benthic invertebrate density of Nematoda (phylum), Oligochaeta (subclass), Polychaeta (class), and Amphipoda (class) between the Project Area and Reference Areas Pre(MRPP, $\mathrm{T}=-2.65, \mathrm{P}=0.02$ ) and Post-Restoration (MRPP, $\mathrm{T}=-1.28, \mathrm{P}=0.10$ ). Statistically significant differences within treatment periods are shown with letters above density bars.

capitata (Polychaeta; 7\% of all species). Indicator Species Analysis found 10 of 73 taxa to be strongly significant indicators of Reference Areas prior to restoration, including Pseudopolydora kempi (Polychaeta), S. benedicti (Polychaeta), C. capitata (Polychaeta), Monocorophium insidiosum (Amphipoda), Grandidierella japonica (Amphipoda), and Gemma gemma (Mollusca; Monte Carlo, all $\mathrm{P} \leq 0.001$ ).

\subsubsection{Changes in Project Area with Restoration}

Benthic invertebrate densities within the Project Area increased by 530\% after restoration (GLM, $\mathrm{df}=1, \mathrm{~F}=$ 28.04, $\mathrm{P}<0.001$, square-root transformed). Post-Restoration densities in the Project Area averaged $0.80 \pm 0.13$ inverts $/ \mathrm{cm}^{3}$, with a median density of 0.63 inverts $/ \mathrm{cm}^{3}$ (Figure 4). Mean species richness in the Project Area increased significantly from $16.4 \pm 2.5$ species Pre-Restoration to $30.9 \pm 1.7$ species Post-Restoration (GLM, df $=$ $1, \mathrm{~F}=24.66, \mathrm{P}<0.001)$. Species diversity also increased in the Project Area $\left(\mathrm{H}^{\prime}=1.77 \pm 0.07 ; \mathrm{GLM}, \mathrm{df}=1, \mathrm{~F}\right.$ $=6.7, \mathrm{P}=0.017)$. MRPP analysis suggested significant shifts in species composition between Pre- and PostRestoration periods in the Project Area (MRPP, $\mathrm{df}=1, \mathrm{~T}=-11.27, \mathrm{P} \leq 0.001$ ) and Reference Areas (MRPP, $\mathrm{df}$ $=1, \mathrm{~T}=-8.70, \mathrm{P}<0.001)$.

\subsubsection{Convergence with Natural Marshes}

Reference Areas also had a large (198\%) increase in average benthic invertebrate density after 2008. Post-Restoration, the Reference Areas averaged $1.68 \pm 0.3$ inverts $/ \mathrm{cm}^{3}$, with a median density of 1.28 inverts $/ \mathrm{cm}^{3}$ (Figure 4). Due to large increases in both Study Areas, abundances within the restored wetland continued to differ significantly from Reference Areas (GLM, $\mathrm{df}=1, \mathrm{~F}=6.03, \mathrm{P}=0.02$, log-transformed; Figure 4).

Changes in species richness in Reference Areas between restoration periods were also significant (GLM, $\mathrm{df}=$ $1, \mathrm{~F}=6.52, \mathrm{P}=0.017)$. During Post-Restoration, species diversity between Study Areas was similar (GLM, $\mathrm{df}=$ $1, \mathrm{~F}=1.53, \mathrm{P}=0.226)$, while species richness continued to vary $(\mathrm{GLM}, \mathrm{df}=1, \mathrm{~F}=12.10, \mathrm{P}=0.002)$, with lower levels of species richness in the Project Area (30.9 \pm 1.7$)$ than Reference Areas (41.3 \pm 2.6$)$.

After restoration occurred, the Study Areas continued to show differences in benthic invertebrate species assemblages (MRPP, $\mathrm{df}=1, \mathrm{~T}=-2.96, \mathrm{P}=0.014)$. NMS indicated that, while the group of Project Area sites had moved closer to that of the Reference Areas, they had not fully converged (NMS, Final Stress $=14.79$, 2D solution, in stab $<0.0001$, 45 iter; Figure 5(b)). Axis 2 accounted for most of the separation between Post-Restoration Study Areas (Axis 2 GLM, df = 1, F = 87.13, P < 0001). Salinity was the only environmental factor that appeared to affect spatial distribution of Post-Restoration sampling sites in NMS (Figure 5(b)) and also showed 
a significant relationship with species composition between sampling sites $\left(\mathrm{GLM}, \mathrm{df}=1, \mathrm{~F}=4.18, \mathrm{P}=0.05 ; \mathrm{R}^{2}\right.$ $=31 \%)$.

After 2008, the Study Areas had a similar mix of higher order invertebrate taxa (MRPP, $\mathrm{df}=1, \mathrm{~T}=-1.28, \mathrm{P}=$ 0.10). Oligochaetes remained the most common invertebrate group in Reference Areas $\left(0.40 \pm 0.08\right.$ inverts $\left./ \mathrm{cm}^{3}\right)$ and a common one in the Project Area $\left(0.21 \pm 0.05\right.$ inverts $\left./ \mathrm{cm}^{3}\right)$, as well (Figure 6). Amphipods were seemingly the most prevalent invertebrate group in the restored wetland $\left(0.39 \pm 0.1\right.$ inverts $/ \mathrm{cm}^{3}$; Figure 6$)$. The three most common lower-order taxonomic groups in the restored Project Area were Paracorophium (Amphipoda; 34\% of all species), M. insidiosum (Amphipoda; $11 \%$ of species), and S. benedicti (Polychaeta; $7 \%$ of all species), although the only strong indicator species of the restored wetland were Eogammarus confervicolus (Amphipoda) and Gnorimosphaeroma insulare (Isopoda); Monte Carlo, all P < 0.01).

In Reference Areas, the most common taxonomic groups were Paracorophium (Amphipoda; 15\% of species), S. benedicti (Polychaeta; 14\% of all species), Pygospio elegans (Polychaeta; 5\% of all species), and M. insidiosum (Ampipoda, 3\% of all species). Despite similarities between prevalent species among Study Areas, Indicator Species Analysis found a considerable number of species that discriminated between the Post-Restoration Project Area and Reference Areas. Eleven taxa were identified as being indicative of natural marshes, with the strongest indicators being Lineidae (Anopla), P. elegans, Nebalia kensleyi (Malacostraca), Cumella vulgaris (Arthropoda), Allorchestes angusta (Amphipoda), Psychoda (Diptera), and G. gemma (Mollusca; Monte Carlo, all $\mathrm{P}<0.001)$

\subsection{Fish}

\subsubsection{Baseline Conditions}

The composition of fish species prior to restoration showed strong differences between the Project Area and Reference Areas (MRPP, $\mathrm{df}=1, \mathrm{~T}=-11.67, \mathrm{P}<0.0001$ ). These differences were evident in statistical ordination results, which pointed to salinity and temperature as the primary factors separating fish assemblages between the unrestored dairy ranch and natural marsh sites (NMS, Final Stress $=11.66$, 3D solution instab $=0.001$, 400 iter; Figure 7(a)). Axes 1 and 2 accounted for $65 \%$ of the $81 \%$ of the total variation accounted for by the model, with both axes showing separation between Study Areas (GLM, df = 1, F = 25.07 and 15.99, respectively, $\mathrm{P}<0.0001)$.

Indicator species analysis suggested that the Project Area fish assemblages differed from Reference Area ones by having higher relative abundances of threespine stickleback (Gasterosteus aculeatus); the federally endangered tidewater goby (Eucylogobius newberryi); and mosquitofish (Gambusia affinis; Monte Carlo, all $\mathrm{P}<0.004$ ), while Reference Areas had higher relative abundances of arrow goby (Clevelandia ios), surfperch (Embiotocidae), and goby larvae (Monte Carlo, all $\mathrm{P}<0.05$ ). In addition to mosquitofish, other non-native species present in the Project Area included yellowfin goby (Acanthogobius flavimanus), silver carp (Hypophthalmichthys molitrix), and white crappie (Pomoxis annularis).

Species richness did not differ greatly between the Project Area and Reference Areas prior to restoration. Before restoration, mean number of species ranged from $3.4 \pm 0.2$ in the Project Area to $3.2 \pm 0.2$ in the Reference Areas $(\mathrm{GLM}, \mathrm{df}=1, \mathrm{~F}=0.06, \mathrm{P}=0.81)$.

\subsubsection{Changes in Project Area with Restoration}

Restoration resulted in only a weakly significant change in fish community composition in the Project Area (MRPP, $\mathrm{df}=1, \mathrm{~T}=-1.66, \mathrm{P}=0.07$ ). Species richness in the Project Area remained similar to pre-restoration levels after levee breaching, averaging $3.5 \pm 0.2$ (GLM, $\mathrm{df}=1, \mathrm{~F}=0.07, \mathrm{P}=0.79$ ). Similarly, statistical ordination showed no clear separation between restoration periods within the Project Area based on species and environmental variables (NMS, Final Stress=16.00, 3D solution, instab $=0.036 ; 400$ iter; Kruskal-Wallis, all P for axes $>0.15$ ).

Indicator Species Analysis identified mosquitofish and, to a lesser degree, the Sacramento sucker (Catostomus occidentalis) as most indicative of Pre-Restoration Project Area fish assemblages (Monte Carlo, all P < 0.07). In evaluating Post-Restoration indicator values relative to Pre-Restoration ones, common estuarine species such as threespine stickleback appeared equally abundant in the Project Area between treatment periods, while arrow goby abundance seemingly climbed during Post-Restoration, although neither result was statistically significant (Monte Carlo, all P > 0.21). Relative abundance of tidewater goby, the federally endangered brackish water fish 


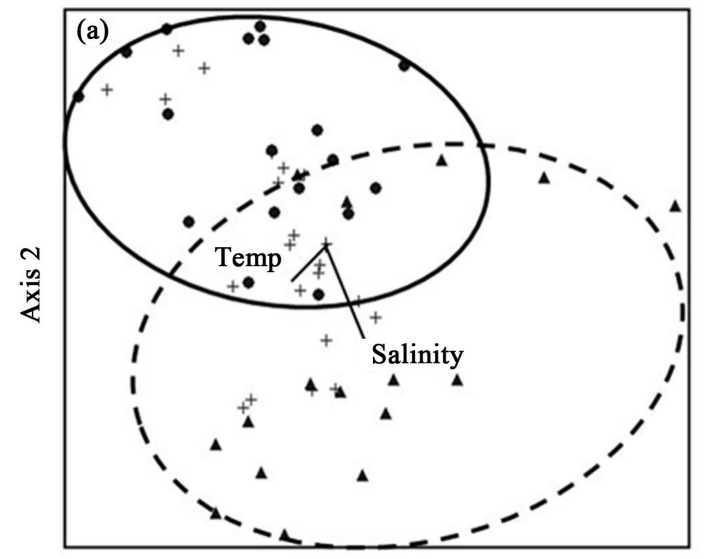

Axis 1

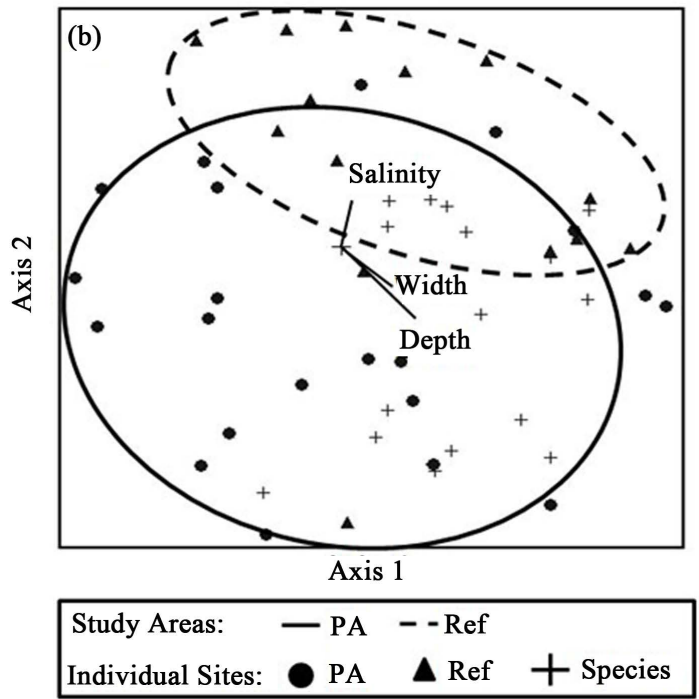

Figure 7. Three-dimensional (3D) statistical ordination of fish species assemblages and environmental variables using Non-metric Multi-dimensional Scaling between Study Areas for (a) Pre-Restoration with joint plot (Final stress = 11.66) and (b) Post-Restoration with joint plot (Final stress $=9.03$ ). Environmental variables did not appear to provide any separation between Study Areas.

that occurred in the Project Area even prior to restoration, did not appear to change with restoration (Monte Carlo, $\mathrm{P}=0.76$ ).

\subsubsection{Convergence with Natural Marshes}

As with Pre-Restoration, fish composition of the Project Area continued to differ strongly from Reference Areas even after restoration (MRPP, $\mathrm{df}=1, \mathrm{~T}=-6.00, \mathrm{P}<0.0001$ ). Statistical ordination showed that only a few Project Area sites overlapped with Reference Area ones (NMS, Final Stress $=9.03$, 3D solution, instab $=0.0004$, 111 iter; Figure 7(b)). Axis 2, which showed the strongest separation of Study Areas, accounted for up to 67\% of the $98 \%$ of total variation $\left(\mathrm{R}^{2}\right)$ explained by the model, suggesting that very strong differences still existed between the Project and Reference Areas four years after levees were removed (GLM, $\mathrm{df}=1, \mathrm{~F}=8.79, \mathrm{P}=$ 0.006). Some separation of Study Areas also occurred along Axis 1, but this axis differentiated sites more on the basis of salinity and width and depth of sampled area, with salinity generally higher within Reference Area sites and width and depth higher in Project Area ones $\left(R^{2}=0.20\right)$.

Based on Indicator Species Analysis, differences between the restored wetland and natural marshes still revolved around a higher relative proportion of arrow goby, surfperch, and longjaw mudsucker (Gillichthys mirabilis; Monte Carlo, all P < 0.09) in Reference Areas. Similar to Pre-Restoration, the Project Area continued to 
support a higher relative abundance of tidewater goby and mosquitofish (Monte Carlo, all $\mathrm{P}<0.04$ ) than natural marshes, as well as sculpin (Cottoidea; Monte Carlo, $\mathrm{P}=0.02$ ).

Comparisons of species richness in the restored marsh with that in natural marshes $(2.8 \pm 0.2)$ continued to suggest that both Study Areas supported roughly the same number of species after 2008 (GLM, $\mathrm{df}=1, \mathrm{~F}=0.32$, $\mathrm{P}=0.58)$.

\subsection{Water Quality}

\subsubsection{Baseline Conditions}

Water salinities differed significantly between the Project Area and other Study Areas prior to restoration (Kruskal-Wallis, $\mathrm{df}=2, \mathrm{H}=472.6, \mathrm{P}<0.001$ ). Median salinities were $1.6 \mathrm{ppt}$ in the Project Area, $25.5 \mathrm{ppt}$ in Reference Areas, and $0.1 \mathrm{ppt}$ in Upstream Areas. Temperatures were also lower in the Project Area (median = $15.1^{\circ} \mathrm{C}$ ) than in Reference Areas (median $=17.3^{\circ} \mathrm{C}$ ), although not lower than those in Upstream Areas (median $=$ $12.7^{\circ} \mathrm{C}$; Kruskal-Wallis, $\mathrm{df}=2, \mathrm{H}=50.0, \mathrm{P}<0.001$ ). Median dissolved oxygen concentrations also showed considerable dissimilarity between the Project Area $(7.58 \mathrm{mg} / \mathrm{L})$, Reference Areas $(8.32 \mathrm{mg} / \mathrm{L})$, and Upstream Areas $(9.51 \mathrm{mg} / \mathrm{L}$; Kruskal-Wallis, $\mathrm{df}=2, \mathrm{H}=38.6, \mathrm{P}<0.001)$. Oxygen levels averaged as low as $4.98 \pm 0.24$ $\mathrm{mg} / \mathrm{L}$ in the eastern portion of the dairy ranch. In contrast, median $\mathrm{pH}$ did not vary significantly between the Project Area and the other Study Areas prior to restoration (range=7.60 to 7.63; Kruskal-Wallis, $\mathrm{df}=2, \mathrm{H}=5.1$, $\mathrm{P}=0.08)$.

\subsubsection{Changes in Project Area with Restoration}

A significant change in average salinities occurred within the Project Area after restoration. Average salinities climbed 70\% from $6.9 \pm 0.3$ ppt pre-restoration to $11.7 \pm 0.5 \mathrm{ppt}$ post-restoration (GLM, $\mathrm{df}=2, \mathrm{~F}=41.9$, $\mathrm{P}<$ 0.0001; sqrt transformed for analysis). Median salinities followed a similar pattern, climbing from $1.6 \mathrm{ppt}$ before restoration to $10.8 \mathrm{ppt}$ after restoration. Following restoration, mean oxygen levels in the Project Area increased $14 \%$ from $7.30 \pm 0.13 \mathrm{mg} / \mathrm{L}$ pre-restoration to $8.30 \pm 0.14 \mathrm{mg} / \mathrm{L}$ post-restoration $(\mathrm{GLM}$, $\mathrm{df}=2, \mathrm{~F}=24.3, \mathrm{P}<$ 0.0001; log transformed for analysis). Conversely, median temperatures dropped by $6 \%$ in the Project Area after restoration from $15.1^{\circ} \mathrm{C}$ to $14.1^{\circ} \mathrm{C}($ Mood Median Test, $\mathrm{df}=2$, Chi-Square $=8.84, \mathrm{P}=0.012)$. Mean $\mathrm{pH}$ in the Project Area also declined after levee breaching, dropping approximately 5\% from $7.58 \pm 0.02$ during Pre-Restoration to $7.21 \pm 0.02$ during Full Restoration (GLM, $\mathrm{df}=2, \mathrm{~F}=70.3, \mathrm{P}<0.0001$ ).

\subsubsection{Convergence with Natural Marshes}

Four years following restoration, $\mathrm{pHs}$ in the Project Area and Reference Areas still differed from each other (GLM, df $=1, \mathrm{~F}=10.1, \mathrm{P}=0.002$ ), with $\mathrm{pH}$ averaging $7.21 \pm 0.02$ in the Project Area and $7.32 \pm 0.03$ in the Reference Areas. Salinities also remained somewhat dissimilar between Study Areas, although differences were only weakly significant (GLM, $\mathrm{df}=1, \mathrm{~F}=4.3, \mathrm{P}=0.067$ ). Salinities averaged $11.7 \pm 0.5$ in the Project Area and $19.8 \pm 0.7$ in Reference Areas after restoration. Other variables, however, showed some convergence between restored and natural marshes. Oxygen levels between the two Study Areas after restoration were equivalent from a statistical perspective: $8.30 \pm 0.14 \mathrm{mg} / \mathrm{L}$ in the Project Area and $8.86 \pm 0.36 \mathrm{mg} / \mathrm{L}$ in Reference Areas (GLM, $\mathrm{df}=1, \mathrm{~F}=1.09, \mathrm{P}=0.30$, log-transformed for analysis). Average temperatures after restoration also did not differ significantly between the Project Area $\left(15.2^{\circ} \mathrm{C} \pm 0.2^{\circ} \mathrm{C}\right)$ and Reference Areas $\left(15.3^{\circ} \mathrm{C} \pm 0.3^{\circ} \mathrm{C}\right.$; $\mathrm{GLM}, \mathrm{df}=1$, $\mathrm{F}<0.0001, \mathrm{P}=0.991)$.

\section{Discussion}

\subsection{Convergence with Natural Tidal Marshes}

Thus far, the effects of restoration on the Giacomini Wetland food web have been considerably dissimilar to those of previous tidal wetland restoration projects. Whereas other projects have often documented a strong and immediate response to restoration within fish communities, restoration at Giacomini has not produced any significant change in fish species assemblages or species richness in the four years since construction, although any changes may have been obscured, in part, by our sampling approach. Conversely, one of the parameters that other studies suggested can take decades to respond—benthic invertebrates—has already shown a strong response to restoration, with densities and species richness, diversity, and composition changing considerably 
post-resto- ration. Species assemblages, richness, and diversity of zooplankton species also shifted significantly in the restored wetland after levees were removed, but, unlike benthic invertebrates, abundance of zooplankton actually decreased in both the Project Area and Reference Areas after 2008.

With these changes, both zooplankton and benthic invertebrate communities have started converging with those of natural marshes, although convergence is not yet complete. Median densities, species richness, and species diversity of zooplankton were statistically equivalent between the restored wetland and natural marshes after four years, as was diversity of benthic invertebrate species. In addition, based on ordination and other multivariate analyses, species composition of zooplankton and benthic invertebrate assemblages in the Project Area have also moved closer to those in Reference Areas. Benthic invertebrate densities and species richness in Giacomini still differed from those of post-restoration natural marshes, although post-restoration densities in the restored wetland were remarkably similar to pre-restoration ones in natural marshes.

\subsection{Role of Environmental and Climatic Factors}

Salinity was one of the strongest drivers of change in the Project Area species assemblages following restoration, as well as being the strongest driver of continued differences in community assemblages between the restored wetland and natural marshes. Project Area waters have become more saline with reintroduction of tidal flow. Salinity changes may have directly affected invertebrate assemblages, but they could also represent a surrogate for other changes brought about by restoration, including reduced water impoundment, improved water quality, and higher oxygen levels in sediments, which encourages more colonization by benthic invertebrates. Interestingly, higher salinities in the restored wetlands appear to be associated with increases in benthic invertebrate densities, but decreases in zooplankton abundance, although statistical analyses pointed to water temperature having a stronger effect than salinity on zooplankton densities in the restored and natural marshes.

Similar trends in invertebrate density changes between Study Areas after 2008 suggests that restoration may not be the only factor effecting change. At Limantour, increases in benthic invertebrate density could be potentially attributed to a restoration project that occurred upstream in 2008, however, density increases were observed in all of the natural marshes monitored. A more likely explanation for system-wide shifts is that organisms are responding to changes in rainfall patterns. While the post-restoration period was slightly wetter than the pre-restoration one in terms of annual rainfall, rainfall totals in the fall were actually lower after restoration (Western Regional Climate Center, Olema Valley). Lower rainfall means less freshwater entering wetlands, which can increase water salinities. Less freshwater inflow can also decrease erosion of the sediment substrate and minimize fluctuating sediment salinity levels. Benthic invertebrate communities can be greatly depressed by the scouring effect of large storm events and dramatic changes in sediment salinity levels [28]. Therefore, while restoration did influence changes in benthic invertebrate and zooplankton communities in the Project Area, climatic factors may have played a role, as well. The role that climate plays in shaping of these communities may be further intensified in future years with global climate change potentially leading to greater unpredictability in both intra- and inter-annual rainfall [29].

While restoration may promote convergence between Study Areas, complete convergence may not be possible due to fundamental hydrologic differences between these systems. For fish, restoration may be less important to community dynamics, at least to this point, than hydrologic factors such as the amount of freshwater inflow. Project Area waters are generally more brackish, even in summer, than those of the natural marshes due to higher groundwater and freshwater inflow rates. The Study Areas supported similar numbers of fish species before and after restoration, but the type of species found continued to differ between them, with the Project Area supporting more species such as sculpin, stickleback, and tidewater goby and natural marshes supporting more arrow goby, topsmelt, and surfperch. Restoration appeared to affect fish communities in the restored wetland primarily through reducing abundance of non-native species such as mosquitofish, yellowfin goby, white crappie, and silver carp. Similarly, while the restored Project Area did support three of the four most common benthic invertebrate species in natural marshes, differences in hydrologic regimes between Study Areas could lead to persistent differences in invertebrate species assemblages, although even hydrology of these areas could begin to converge in the future due to salinity intrusion associated with sea level rise and changes in precipitation totals and patterns.

\subsection{Role of Invasive Species}

Perhaps one of the most notable differences between the restored wetland and its natural counterparts was that 
the Reference Areas supported a considerable number of opportunistic, invasive invertebrates both before and after 2008, but even four years after levee removal, the Project Area largely did not. Based on results of other studies, newly restored wetlands are often quickly colonized by a large, if not species-rich, group of opportunistic non-native species that eventually gives way to a more stable assemblage dominated by both opportunistic taxa and those more characteristic of natural marshes [13] [30] [31]. Opportunistic species may take advantage of restoration-related disturbance to become the dominant fauna [3] [13] [15] [30] [31]. In some instances, however, numbers of invasives have been higher in reference wetlands than restored ones [9]. Many of the opportunist species found in natural marshes were polychaetes such as $S$. benedicti, P. elegans, and C. capitata, as well as species from other orders such as Bivalvia (G. gemma). Of these species, only S. benedicti occurred in any real numbers within the restored wetland by Year 4 . Non-invasive taxa such as oligochaetes have a limited dispersal stage [13], which may hamper colonization of restored areas, although oligochaetes were the dominant invertebrate taxa at both Giacomini and natural marshes. The restored marsh also supported very high numbers of amphipods such as Paracorophrium, M. insidiosum, and E. confervicolus. Amphipods are generally much lower in abundance in created marshes than natural ones [10], which may relate to their pollution intolerance [32].

\subsection{Role of Restoration Approach}

Ultimately, evolution of benthic invertebrate and perhaps even zooplankton communities in the restored wetland may have been strongly influenced by the level of disturbance associated with restoration. Newly restored areas in other systems are often defaunated during the restoration process by placement of dredge spoil; extensive excavation of channels, channel bottoms, or marshplains; or other substrate-disturbing procedures [31]. Almost every one of the previous studies that evaluated benthic invertebrate communities used marshes that were built with dredge spoil material, which was one of the earliest tidal marsh restoration techniques. Dredge spoil marshes are typically created from excavation of shipping lanes and other subtidal or intertidal areas and placement of dredged material into low to high intertidal zones [33]. Dredge spoil soils vary in texture, but many used for marsh creation have tended to be very sandy [33] [34]. Several studies have found that soils of dredge spoil marshes have higher sand, less clay, and less organic matter, including MOM, than adjacent natural marshes [10] [12] [35] [36].

The likelihood that systems with markedly different soils would develop similar infauna communities seems extremely low. Some of the sites where benthic invertebrate communities evolved more quickly were ones where dikes were breached [37] or uplands were excavated [3], although some culvert replacement projects where substrate was not necessarily disturbed still had invertebrate communities that had not converged with reference marshes [4].

The minimalistic approach used to restore the Giacomini Wetlands (removal of levees from non-tidal and muted tidal areas with minimal excavation) appears to have placed this wetland on a slightly different evolutionary trajectory than those of more disturbance-intensive projects. The reduced scale of substrate disturbance during restoration may have preserved some remnant of the original benthic community in sheltered areas that were not directly exposed to tidal scour or abrupt increases in water salinity. Recolonization of disturbed areas typically occurs through lateral advection of either adult organisms (often opportunistic invaders) or juveniles, and recolonization dynamics are often governed by the extent of restoration-related ground disturbance and the proximity of source areas or "pools" [12] [30] [31]. The natural marsh that directly adjoins the restored wetland represents a sizeable source of potential colonizing organisms. Rapid recovery of benthic infauna may have also been promoted by the fact that unexcavated marsh soils probably retained considerable organic matter, particularly MOM, which many studies have found to be strongly linked to benthic community development [3] [10]-[12] [15] [20].

\subsection{Ultimate Determinant of Success-Higher Level Trophic Support}

Documented changes in invertebrate and, to a lesser degree, fish communities will have dramatic repercussions on higher trophic level organisms such as larger fish and birds. While waterfowl responded almost immediately to restoration of the Project Area, arriving in high numbers only a month after levees were breached, shorebird numbers during the first winter were quite low [38]. In subsequent years, shorebird numbers have increased, although abundance has been variable intra- and inter-annually [38]. Some of the more recent frequent visitors to 
the restored wetland include species such as marbled godwits (Limosa fedoa), dunlin (Calidris alpina), and dowitchers (Limnodromus spp.), which are deeper substrate probers [38]. These results would seemingly confirm our findings that benthic invertebrate resources are increasing, as the pattern of fish and bird use would be expected to evolve in concert with that of the lower trophic levels.

\section{Conclusions}

Our fish and invertebrate monitoring results differ considerably from those of other tidal wetland restoration projects. Studies in other systems have shown that fish communities similar to those of natural marshes can rapidly establish in constructed or restored marshes, while invertebrate communities can take decades to reach equivalency [9]-[12]. These differences may ultimately relate to the restoration approach taken by these projects, with more minimalistic approaches allowing for more rapid development of invertebrate communities and for less establishment by non-native opportunistic species that take advantage of restoration disturbance to rapidly colonize restored marshes. Avian monitoring of waterfowl and shorebird use conducted in the restored wetland suggests that trophic development is occurring [38].

Non-native species introduce a "wild-card" factor into the evolution of the newly restored Giacomini Wetlands. Unlike many other restored or constructed tidal marshes, invertebrate species assemblages in the restored wetland have so far not become dominated by opportunistic species, but this somewhat atypical dynamic may shift in future years, given the high number of non-native species present in adjacent natural marshes. Continued differences in hydrologic conditions between the brackish Giacomini Wetlands and its more saline tidal marsh counterparts may help, at least in part, to preclude or minimize establishment by some of these species. However, salinity intrusion associated with sea level rise and inter-annual climatic variability, which may only increase in future years [29], could ultimately homogenize hydrologic differences between these systems.

In this case, then, convergence of the restored wetland with natural marshes may not be desirable, at least in terms of invertebrate communities. Non-native invertebrates can severely disrupt the food chain within estuaries by eliminating traditional diet items and supplanting them with lower-quality or unpalatable ones, as has been seen in nearby San Francisco Bay with introduction of the non-native, invasive Asian clam (Corbula amurensis) and subsequent dramatic declines in native copepod species and native fish such as northern anchovy (Engraulis mordax) and juvenile salmon [39].

Unlike San Francisco Bay, the historical ecology of Tomales Bay is not well known, so it is difficult to determine how much impact to the food web these invaders have had on the estuary, and will have on the restored wetland. Ultimately, the success of this and other restoration projects in supporting both lower and higher tropic levels of wildlife may not depend on internal factors such as success of restoration efforts, but instead on extrinsic factors such as short-term or long-term climatic patterns and presence or abundance of non-native species within the watershed.

\section{References}

[1] Williams, G.D. and Zedler, J. (1999) Fish Assemblage Composition in Constructed and Natural Tidal Marshes of San Diego Bay: Relative Influence of Channel Morphology and Restoration History. Estuaries, 22, 702-716. http://dx.doi.org/10.2307/1353057

[2] Desmond, J.S., Deutschman, D. and Zedler, J. (2002) Spatial and Temporal Variation in Estuarine Fish and Invertebrate Assemblages: Analysis of an 11-Year Data Set. Estuaries, 25, 552-569. http://dx.doi.org/10.1007/BF02804890

[3] Havens, K.J., Varnell, L. and Watts, B. (2002) Maturation of a Constructed Tidal Marsh Relative to Two Natural Reference Tidal Marshes over 12 Years. Ecological Engineering, 18, 305-315. http://dx.doi.org/10.1016/S0925-8574(01)00089-1

[4] Warren, R.S., Fell, P., Rozsa, R., Brawley, A., Orsted, A., Olson, E., Swamy, V. and Niering, W. (2002) Salt Marsh Restoration in Connecticut: 20 Years of Science and Management. Restoration Ecology, 10, 497-513. http://dx.doi.org/10.1046/j.1526-100X.2002.01031.x

[5] Konisky, R.A., Burdick, D., Dionne, M. and Neckles, H. (2006) A Regional Assessment of Salt Marsh Restoration and Monitoring in the Gulf of Maine. Restoration Ecology, 14, 516-525. http://dx.doi.org/10.1111/j.1526-100X.2006.00163.x

[6] Kimball, M.E. and Able, K. (2007) Tidal Utilization of Nekton in Delaware Bay Restored and Reference Intertidal Salt Marsh Creeks. Estuaries and Coasts, 30, 1075-1087. http://dx.doi.org/10.1007/BF02841397 
[7] Chamberlain, R.H. and Barnhart, R. (1993) Early Use by Fish of a Mitigation Salt-Marsh, Humboldt Bay, California. Estuaries, 16, 769-783. http://dx.doi.org/10.2307/1352435

[8] Raposa, K.B. (2008) Early Ecological Responses to Hydrologic Restoration of a Tidal Pond and Salt Marsh Complex in Narragansett Bay, Rhode Island. Journal of Coastal Research, 55,180-192. http://dx.doi.org/10.2112/SI55-015

[9] Minello, T.J. and Webb, J. (1997) Use of Natural and Created Spartina alterniflora Salt Marshes by Fishery Species and Other Aquatic Fauna in Galveston Bay, Texas, USA. Marine Ecology Progress Series, 151, 165-179. http://dx.doi.org/10.3354/meps151165

[10] Minello, T.J. and Zimmerman, R. (1992) Utilization of Natural and Transplanted Texas Salt Marshes by Fish and Decapod Crustaceans. Marine Ecology Progress Series, 90, 273-285. http://dx.doi.org/10.3354/meps090273

[11] Talley, T.S. and Levin, L. (1999) Macrofaunal Succession and Community Structure in Salicornia Marshes of Southern California. Estuarine, Coastal and Shelf Science, 49, 713-731. http://dx.doi.org/10.1006/ecss.1999.0553

[12] Ferguson, H.J. and Rakocinski, C. (2008) Tracking Marsh Restoration Using Macrobenthic Metrics: Implementing a Functional Approach. Wetlands Ecology and Management, 16, 277-289. http://dx.doi.org/10.1007/s11273-008-9088-4

[13] Levin, L.A., Talley, D. and Thayer, G. (1996) Succession of Macrobenthos in a Created Salt Marsh. Marine Ecology Progress Series, 141, 67-82. http://dx.doi.org/10.3354/meps141067

[14] Bolam, S.G., Schratzberger, M. and Whomersley, P. (2006) Macro- and Meiofaunal Recolonisation of Dredged Material Used for Habitat Enhancement: Temporal Patterns in Community Development. Marine Pollution Bulletin, 52, 1746-1755. http://dx.doi.org/10.1016/j.marpolbul.2006.07.010

[15] Moseman, S.M., Levin, L., Currin, C. and Forder, C. (2004) Colonization, Succession, and Nutrition of Macrobenthic Assemblages in a Restored Wetland at Tijuana Estuary, California. Estuarine, Coastal and Shelf Science, 60, 755-770. http://dx.doi.org/10.1016/j.ecss.2004.03.013

[16] LaSalle, M.W., Landin, M. and Sims, J. (1991) Evaluation of the Flora and Fauna of a Spartina alterniflora Marsh Established on Dredged Material in Winyah Bay, South Carolina. Wetlands, 11, 191-208. http://dx.doi.org/10.1007/BF03160849

[17] Posey, M.H., Alphin, T. and Powell, C. (1997) Plant and Infaunal Communities Associated with a Created Marsh. Estuaries, 20, 42-47. http://dx.doi.org/10.2307/1352718

[18] Craft, C. and Sacco, J. (2003) Long-Term Succession of Benthic Infauna Communities on Constructed Spartina alterniflora Marshes. Marine Ecology Progress Series, 257, 45-58. http://dx.doi.org/10.3354/meps257045

[19] Cordell, J.R., Bollens, S., Draheim, R. and Sytsma, M. (2008) Asian Copepods on the Move: Recent Invasions in the Columbia-Snake River System, USA. ICES Journal of Marine Science, 65, 753-758. http://dx.doi.org/10.1093/icesjms/fsm195

[20] Parsons, L.S. and Ryan, A.B. (2015) Year Five of the Giacomini Wetland Restoration Project: Analysis of Changes in Physical and Ecological Conditions in the Project Area. Point Reyes National Seashore.

[21] Tomales Bay Watershed Council (2003) The Tomales Bay Watershed Stewardship Plan: A Framework for Action. 137 p.

[22] Anima, R. (1991) Pollution Studies of Drakes Estero, and Abbotts Lagoon Point Reyes National Seashore, California, USA. U.S. Geological Survey Report, Open File Report, 91-145.

[23] Livingston, D. (1994) Ranching on the Point Reyes Peninsula: A History of the Dairy and Beef Ranches within Point Reyes National Seashore, 1834-1992. Historic Resource Study, National Park Service, Point Reyes National Seashore.

[24] KHE (2009) Olema Marsh Restoration: Salinity Impact Assessment Study. Prepared for Point Reyes National Seashore, Draft, September 2009.

[25] Phillip Williams \& Associates, Ltd. (PWA) (1993) An Evaluation of the Feasibility of Wetland Restoration on the Giacomini Ranch. Prepared for the National Park Service, Marin County, Contract \#CX8140-1-0024.

[26] Smith, E.R. (2002) BACI Design. In: El-Shaarawi, A.H. and Piegorsch, W.M., Eds., Encyclopedia of Environmetrics, John Wiley \& Sons, Ltd., Chichester, 141-148.

[27] Levin, L.A., Talley, T. and Hewitt, J. (1998) Macrobenthos of Spartina foliosa (Pacific Cordgrass) Salt Marshes in Southern California: Community Structure and Comparison to a Pacific Mudflat and a Spartina alterniflora (Atlantic Smooth Cordgrass) Marsh. Estuaries, 21, 129-144. http://dx.doi.org/10.2307/1352552

[28] Nordby, C.S. and Zedler, J. (1991) Responses of Fish and Macrobenthic Assemblages to Hydrologic Disturbances in Tijuana Estuary and Los Penasquitos Lagoon, California. Estuaries, 14, 80-93. http://dx.doi.org/10.2307/1351985

[29] Cayan, D., Tyree, M. and Iacobellis, S. (2012) Climate Change Scenarios for the San Francisco Region. California Energy Commission, Publication No. CEC-500-2012-042, Scripps Institution of Oceanography, San Diego.

[30] Alphin, T.D. and Posey, M. (2000) Long-Term Trends in Vegetation Dominance and Infaunal Community Composition in Created Marshes. Wetlands Ecology and Management, 8, 317-325. http://dx.doi.org/10.1023/A:1008435319922 
[31] Zajac, R.N. and Whitlatch, R. (2001) Response of Macrobenthic Communities to Restoration Efforts in a New England Estuary. Estuaries, 24, 167-183. http://dx.doi.org/10.2307/1352942

[32] Nelson, S.M., Roline, R., Thullen, J., Sartoris, J. and Boutwell, J. (2000) Invertebrate Assemblages and Trace Element Bioaccumulation Associated with Constructed Wetlands. Wetlands, 20, 406-415.

http://dx.doi.org/10.1672/0277-5212(2000)020[0406:IAATEB]2.0.CO;2

[33] Zeder, J.B. (2000) Handbook for Restoring Tidal Wetlands. CRC Press, Boca Raton, 464 p.

[34] Harding Lawson Associates (HLA) (2000) The Beneficial Reuse of Dredged Material for Upland Disposal. Prepared for Port of Long Beach, Long Beach, HLA Project No. 48881.

[35] Langis, R., Zalejko, M. and Zedler, J. (1991) Nitrogen Assessments in a Constructed and a Natural Salt Marsh of San Diego Bay. Ecological Applications, 1, 40-51. http://dx.doi.org/10.2307/1941846

[36] Sacco, J.N., Seneca, E.D. and Wentworth, T.R. (1994) Infaunal Community Development of Artificially Established Salt Marshes in North Carolina. Estuaries, 17, 489-500. http://dx.doi.org/10.2307/1352678

[37] Eertman, R.H., Kornman, B., Stikvoort, E. and Verbeek, H. (2002) Restoration of the Sieperda Tidal Marsh in the Scheldt Estuary, the Netherlands. Restoration Ecology, 10, 438-449. http://dx.doi.org/10.1046/j.1526-100X.2002.01034.x

[38] Avocet Research Associates (2012) Giacomini Marsh Wetland Restoration Avian Winter Surveys: Year-5 (2012-2013), Early Season Results. Prepared for Point Reyes National Seashore, 26 December 2012.

[39] Kimmerer, W.J. and Orsi, J. (1996) Changes in the Zooplankton of the San Francisco Bay Estuary Since the Introduction of the Clam Potamocorbula amurensis. In: Hollibaugh, J., Ed., San Francisco Bay: The Ecosystem, Pacific Division American Association for the Advancement of Science, San Francisco, 403-424. 